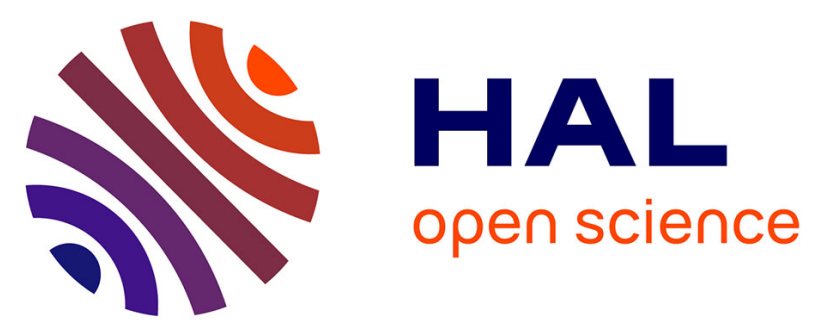

\title{
Effect of immigration on multiple sclerosis sex ratio in Canada: the Canadian Collaborative Study
}

Sarah-Michelle Orton, Sreeram V Ramagopalan, Denise Brocklebank, Blanca

M Herrera, David A Dyment, Irene M Yee, a Dessa Sadovnick, George C Ebers

\section{To cite this version:}

Sarah-Michelle Orton, Sreeram V Ramagopalan, Denise Brocklebank, Blanca M Herrera, David A Dyment, et al.. Effect of immigration on multiple sclerosis sex ratio in Canada: the Canadian Collaborative Study. Journal of Neurology, Neurosurgery and Psychiatry, 2009, 81 (1), pp.31. 10.1136/jnnp.2008.162784. hal-00552724

\section{HAL Id: hal-00552724 \\ https://hal.science/hal-00552724}

Submitted on 6 Jan 2011

HAL is a multi-disciplinary open access archive for the deposit and dissemination of scientific research documents, whether they are published or not. The documents may come from teaching and research institutions in France or abroad, or from public or private research centers.
L'archive ouverte pluridisciplinaire HAL, est destinée au dépôt et à la diffusion de documents scientifiques de niveau recherche, publiés ou non, émanant des établissements d'enseignement et de recherche français ou étrangers, des laboratoires publics ou privés. 
Effect of immigration on multiple sclerosis sex ratio in Canada: the Canadian Collaborative Study

Sarah-Michelle Orton ${ }^{1}$, Sreeram V Ramagopalan ${ }^{1}$, Denise Brocklebank ${ }^{1}$, Blanca M. Herrera $^{1}$, David A Dyment ${ }^{1}$, Irene M.Yee ${ }^{2}$, A. Dessa Sadovnick ${ }^{2}$, and George C. Ebers $^{1} *$

\section{Authors affiliations and addresses:}

${ }^{1}$ Wellcome Trust Centre for Human Genetics and Department of Clinical Neurology, University of Oxford; Oxford, UK (SMO, APM, BMH, SVR, MRL, MJC, GCE)

${ }^{2}$ Department of Medical Genetics and Faculty of Medicine, Division of Neurology, University of British Columbia; Vancouver, Canada (ADS, IY)

* To whom correspondence and reprint requests should be addressed

Professor George C Ebers

University Department of Clinical Neurology

West Wing, John Radcliffe Hospital

Oxford OX3 9DU, UK

Tel: +44 1865231911 Fax: +44 1865231914

george.ebers@clneuro.ox.ac.uk

S-MO is funded by a Clarendon fund studentship. The MS Society of Canada Scientific Research Foundation funds the CCPGSMS. 


\section{ABSTRACT}

Background: The ratio of female to male (F:M) MS cases varies geographically, generally being greater in areas of high prevalence. In many regions, including Canada, rising MS incidence in women has been implied by the marked increase in F:M ratio.

Methods: We examined the F:M ratio over time in MS patients in the Canadian Collaborative Study born outside of Canada, with onset post-migration $(n=2531)$. We compared the trends to native-born Canadians, by region of origin and age at migration.

Results: Regression analysis showed that year of birth (y.o.b.) was a significant predictor of sex ratio in immigrants $\left(\chi^{2}=21.4, p<0.001\right.$ correlation $\left.r=0.61\right)$. The rate of change of sex ratio was increasing in all migrant subgroups (by a factor of 1.16 per $10 \mathrm{y}$ period, $p<0.001$ ), with the steepest increase observed in those from Southern Europe $(1.27 / 10 \mathrm{y}, p<0.001)$. The overall immigrant $\mathrm{F}$ :M ratio was 2.17 , but varied by country of origin. It was significantly lower in migrants from Southern Europe compared to Northern Europe or USA (1.89 vs 2.14 and 2.86, $p=0.023$ and $p=0.0003$, respectively). Increasing age at immigration was associated with decreasing sex ratio $(p=0.041)$. The sex ratio of individuals migrating $<21$ was significantly higher than those migrating $\geq 21(2.79 v s 1.96, p=0.004)$.

Conclusions: MS Sex ratio in immigrants to Canada is increasing but variable by region of origin and influenced by age at migration. The findings highlight the importance of environmental effect(s) in MS risk, which are likely gender-specific. 


\section{INTRODUCTION}

In many regions around the world the incidence of MS appears to be rising ${ }^{1-13}$. Although this had been widely ascribed to improved ascertainment, studies in Canada showed this was a real increase ${ }^{14}$; year of birth (y.o.b.) was a significant predictor of sex ratio over more than 5 decades $\left(p<1.0^{-28}\right)$. The sex ratio in Canada, once near unity, is now in excess of 3.21: $1^{14}$. There is no evidence to suggest decreasing incidence in males and time to diagnosis did not differ by gender in the CCPGSMS. The cause for growing female preponderance is not clear, but its speed implicates changing environment or gene-environment interactions.

As with incidence, MS sex ratio is geographically variable and there are various regions worldwide that have much lower sex ratios ${ }^{415}$ compared to Canada and other high risk regions ${ }^{16-19}$. If a relative under-representation of women is responsible for lower prevalence in these locations, this could provide insight into the etiology of sex differences in MS susceptibility and thus the nature of a major environmental factor in the disease. Furthermore, there appears to be national or geographic discontinuity in rising incidence rates ${ }^{20}$, which surely also provides strong clues to its environmentally driven or origin.

Given the high proportion of recent immigrants from disparate regions, and the resources of the Canadian Collaborative Project on Genetic Susceptibility to MS (CCPGSMS), it provides a suitable population to address questions pertaining to variability in MS sex ratio among immigrants. Within this longitudinal cohort, we examined the sex ratio of immigrant MS patients, defined by a birthplace outside of Canada. We asked whether y.o.b. was a significant predictor of sex ratio in 
immigrants and if its rate of change differed from Canadian-born patients. We assessed whether these trends were variable by country of origin, and as MS risk is believed to be largely acquired before adulthood ${ }^{21-24}$, we compared the impact of age at immigration on changing sex ratio. 


\section{METHODS}

\section{Study population}

The Canadian Collaborative Project is an ongoing country-wide longitudinal, population-based study of MS patients in Canada. Detailed information regarding demographics, family history, and clinical features of disease is collected. Details on the study design have been previously published ${ }^{25}$. At the time of data collection (March 2008) we identified 2703 CCPGSMS patients who reported their birth outside of Canada; these subjects are termed 'immigrants' for the purpose of this study.

Sex ratio was calculated simply by dividing the number of female MS cases by the number of male MS cases for each birth year. Five-year moving averages and corresponding confidence intervals (CIs) were calculated for both immigrant and Canadian-born CCPGSMS patients. For illustrative purposes, participants with birth years after 1975 or before $1930(n=346$, mean of 9.2 cases per y.o.b.) are not displayed in the graph as the number of observations is small, especially in the early years. The sex ratios for y.o.b.s $<1930$ and $>1975$ were 1.76 and 3.76 , respectively.

The F:M ratio of the entire Canadian population and all immigrants to Canada was calculated from Statistics Canada census data (2001 census, www.statcan.gc.ca ${ }^{26}$ ). 172 cases were excluded from analyses because MS onset occurred prior to immigration to Canada. Information on birth outside of Canada due to short term vacation, job transfer, or similar short-term departure during mother's pregnancy was not available and thus exclusions could not be made on this basis. Nonetheless the 
authors have found (unpublished data) this number would be very small based on actively searching for such cases by place of birth of MS probands.

\section{Region of Origin and Age at Migration}

To consider possible effects of the country from which an individual emigrated, patients were grouped by the following regional categories, selected based on subgroup sample size: Northern Europe, Europe, USA and Other $(n=1279,480,355$, and 417 , respectively). Over $75 \%$ of immigrants immigrated to Canada before the age of 25 and over $95 \%$ migrated before the age of 35 . We compared the mean sex ratio as well as the rate of change of over time in immigrants from the various regions of origin using the same regression model described for the entire cohort. Approximate percentage increase per 10 year periods were estimated to provide a comparison for the rate of change between regions.

Next we examined the effect of age at immigration to Canada. Age and year at immigration were available for 1547 individuals with MS onset after immigration to Canada. We first used linear regression modeling to test the association of age at immigration with the likelihood of being female. Based on the a priori hypothesis that most MS risk is acquired before adulthood, we then examined the impact of immigrating to Canada in adulthood versus childhood/adolescence. To select a dividing age for adulthood a sliding window approach was used to compare the difference in sex ratios under and over increasing ages at migration. A Bonferroni correction was applied for multiple testing ( $n=5: 12 \mathrm{y}, 15 \mathrm{y}, 18 \mathrm{y}, 21 \mathrm{y}, 24 \mathrm{y})$. The most significant difference in sex ratio was observed at $<21 \mathrm{y}$ versus $\geq 21 \mathrm{y}$, which was then 
used as a cut-off age for analyses. Due to sample size limitations, it was not possible to stratify each age of migration category by y.o.b.

\section{Statistical analysis}

Given that ratios do not follow a normal distribution, ratios were converted to proportions for statistical analyses. To test the significance of birth year as a predictor of sex ratio in immigrant and Canadian-born CCPGSMS cases, we used binomial logistic regression $(n=2531)$. This modelled the true proportion (Py) of women with MS born in each year $(y)$ as: $\ln [\mathrm{Py} /(1-\mathrm{Py})]=\beta$ intercept $+\beta Y O B y$, such that the sex ratio increases by a factor of $\mathrm{e}^{\beta \mathrm{YOB}}$ per 10 year period and the observed number of female patients ( $N F y$ ) is distributed as $N F y \sim \operatorname{Binomial}(\mathrm{Py}, N \mathrm{Fy}+N \mathrm{My}$ ), where $N \mathrm{My}$ is the corresponding number of men with the disease. The likelihood ratio test was used to assess whether $\beta$ YOB was significantly different from zero. All logistic models were analysed in the statistical package $\mathrm{R}^{27}$. Fisher's exact and Chi square tests were used for dichotomous comparisons of number of males versus females by region of origin and age at migration. 


\section{RESULTS}

\section{Immigrant versus Canadian-Born MS patients}

A total of 1853 female and 850 male MS cases were identified from the CCPGSMS with birth reported outside of Canada ("immigrants"). After exclusion for MS onset prior to immigration, the overall F:M ratio is 2.17 (range 1.0 to 4.5, y.o.b.1902 to $1990 n=2531$ ). The mean age of onset was 35 years and the average time between immigration and MS onset was 19.6 years.

The rate of change of sex ratio in CCPGSMS immigrants by birth year is illustrated (Figure 1); the increase is gradual, progressive and similar to Canadian-born participants, albeit with larger variability in the data. Descriptively, it can be seen that there is considerable year-to-year variation in both groups (Figure 1). There was a mean of 51 cases per birth year and 217 cases per 5-year moving average block. The sex ratio by y.o.b. for the entire Canadian population and immigrant population (census data $2001^{26}$ ) are included. No significant deviations from a F:M ratio of unity were observed in the general and immigrant populations in Canada (Figure 1).

Logistic regression modeling showed that y.o.b. is a significant predictor of sex ratio in immigrants to Canada $\left(\chi^{2}=21.4, p<0.001\right)$. The Spearman rank correlation value was $r=0.61(p<0.001)$, somewhat lower than for the entire CCPGSMS $(r=0.84$, $p<0.001)$. Individual y.o.b. data were used in the regression, not moving averages. The exponent of the regression beta coefficient $\left(\beta_{\mathrm{yob}}\right)$ represents the factor by which the sex ratio increases every ten years and the values were similar in the immigrants and Canadian-born individuals ( $\mathrm{e}^{\mathrm{Byob}}=1.157$ and 1.113). $\mathrm{e}^{\mathrm{Byob}}$ is used to estimate an 
approximate overall percentage increase rate in the $\mathrm{F}: \mathrm{M}$ ratio every 10 years. Increases of $3.13 \% / 10 \mathrm{y}$ for the immigrants, compared to $2.82 \% / 10 \mathrm{y}$ for the Canadian-born individuals were observed for the time studied.

\section{MS onset prior to Immigration}

The characteristics of individuals who immigrated to Canada after MS onset differed expectedly from those with onset post-migration. The mean y.o.b, year of onset, year of and age at immigration were all higher than individuals with onset post-migration (Table 1). Conversely, the mean age of onset and year of onset were both lower. The overall mean sex ratio was $2.31(n=172)$ and the correlation of birth year and proportion of females was much lower $(r=0.29, p=0.04)$. There was an average of 7.6 years between clinical onset and immigration to Canada.

\section{Region of Origin}

Sex ratio and its rate of change were variable by immigrants' country of birth. Participants with MS onset post-immigration $(n=2531)$ were analyzed in four region of origin categories (Table 2). Immigrants from the USA and Northern Europe had the highest mean sex ratio, Southern Europe the lowest. We analyzed y.o.b. as a predictor of sex ratio for each region of origin. A rising sex ratio was observed for all regional categories, albeit at different rates (Table 2). Only the increases in sex ratio for Northern Europe and Southern Europe birth region were statistically significant, likely a limitation of sample size (Table 2). The sex ratio among Southern European immigrants, which had the lowest starting point, was increasing most steeply $\left(\mathrm{e}^{\mathrm{Byob}}=\right.$ 1.27 , corresponding to $5.5 \%$ increase per $10 \mathrm{y}$ period, Table 2 ). 
Included in the 'other' region of origin category were patients from various countries in South and North America, Asia, Africa, and Australasia (primarily Australia and New Zealand). This subgroub was diverse, and the regions were variable with respect to background sex ratios. However, none of these sub-populations were of sufficient size for separate analyses, and thus grouped together. Immigrants from Africa and the Middle East had notably lower sex ratios of $2.0(n=45)$ and $1.9(n=66)$, respectively. Individuals emigrating from Asia $(2.9, n=124)$ and Australasia $(4.0, n=45)$ had a high sex ratio.

The largest group of immigrants was from Northern Europe (50.5\%). Within this group approximately $65 \%$ reported UK and Ireland as their region of origin (mean F:M ratio $2.39, n=657)$. The next largest category was from Southern Europe $(19.0 \%$, mean F:M ratio $1.89, n=480$ ), including Italy, France, Greece, Portugal and former Yugoslavia accounting for over $60 \%$ of this group.

The F:M ratio was significantly lower in Southern European migrants compared to those from Northern Europe or USA ( $p=0.023$ and $p=0.0003$, respectively, Fishers Exact test). The odds ratio for likelihood of being female versus male in those with Northern European compared to Southern European country of origin was $1.30(95 \%$ CI 1.042 to $1.61, p=0.019)$.

\section{Age at Immigration}

There was an obvious inverse correlation between age of immigration and sex ratio; the earlier the migration, the higher the sex ratio (Table 2). Individuals who migrated to Canada before their first birthday had a mean sex ratio of 2.9 , and before 5 years it 
was 2.7, slightly higher than the overall CCPGSMS observations (mean ratio 2.4). Conversely, those migrating after age 35 had a sex ratio of 1.75 and close to unity above 50 years old. The mean age at immigration was $16.49 \mathrm{y}$ (range 0 to 66 years, mean year 1967, $n=1547)$.

Using regression analysis, we observed that age at immigration was associated with proportion of Females $(p=0.041)$. We next examined the impact of immigrating to Canada in adulthood versus childhood/adolescence, using $21 \mathrm{y}$ as dividing age for adulthood (Table 2). The most significant difference in sex ratio was observed between those that migrated under age 21 compared to those over and equal to age 21 (Fishers exact test, corrected $p=0.004)$. Descriptively it can be seen that this trend was similar for all regions of origin (Table 2). However, it was only statistically significant for Northern Europe and all immigrants combined, likely due to sample size.

The overall mean F:M ratio in all immigrants who migrated under age 21 was 2.79 (mean y.o.b. of 1951.7) and at or after age 21 was 1.96 (mean y.o.b.1944.3). By comparison, if we take all individuals born in the early 1950s and early 1940s, regardless of age at immigration, the respective sex ratios were 2.27 and 2.09 (see Figure 1). Therefore age at migration appears to be influencing sex ratio independently of y.o.b, although the extent to which the effects are acting independently is unclear. 
Table 1. Characteristics of Dataset

\begin{tabular}{|c|c|c|c|c|}
\hline CCPGSMS patients & All Immigrants & $\begin{array}{l}\text { Onset Post- } \\
\text { immigration }\end{array}$ & $\begin{array}{l}\text { Onset Prior to } \\
\text { Immigration }\end{array}$ & Canadian-born \\
\hline $\begin{array}{l}\text { Number } \\
\text { Sex ratio (Female to Male) } \\
\text { Mean y.o.b. } \\
\text { Min-Max mean sex ratio } \\
\text { per y.o.b. }\end{array}$ & $\begin{array}{c}2703 \\
2.18 \\
1947 \\
1.0-4.0\end{array}$ & $\begin{array}{c}2531 \\
2.17 \\
1947 \\
1.0-4.5\end{array}$ & $\begin{array}{r}172 \\
2.31 \\
1951 \\
-\end{array}$ & $\begin{array}{l}26775 \\
2.51 \\
1952 \\
1.7-4.0\end{array}$ \\
\hline $\begin{array}{l}\text { Mean age at Immigration } \\
\text { Mean year of immigration }\end{array}$ & $\begin{array}{c}18.17 \\
1967(1918-2005)\end{array}$ & $\begin{array}{c}16.49 \\
1965(1918-2004)\end{array}$ & $\begin{array}{c}33.3 \\
1985(1946-2005)\end{array}$ & $\begin{array}{l}-- \\
--\end{array}$ \\
\hline $\begin{array}{l}\text { Mean age of MS onset } \\
\text { Mean year of MS onset }\end{array}$ & $\begin{array}{l}34.3 \\
1982\end{array}$ & $\begin{array}{c}35 \\
1982\end{array}$ & $\begin{array}{l}25.26 \\
1977\end{array}$ & $\begin{array}{c}30 \\
1982\end{array}$ \\
\hline $\begin{array}{l}\text { Spearman Correlation } \\
\text { (y.o.b.. - prop of females) }\end{array}$ & $\begin{array}{l}r=0.581 \\
p<0.001\end{array}$ & $\begin{array}{l}r=0.609 \\
p<0.001\end{array}$ & $\begin{array}{l}r=0.290 \\
p=0.039\end{array}$ & $\begin{array}{l}r=0.832 \\
p<0.001\end{array}$ \\
\hline
\end{tabular}

Table 2. Variation in female to male ratio by region of origin and age at migration

\begin{tabular}{|c|c|c|c|c|c|c|c|c|}
\hline Region & $\begin{array}{c}\text { Total } \\
\mathbf{N}\end{array}$ & $\begin{array}{c}\text { Overall } \\
\text { Mean } \\
\text { Sex } \\
\text { ratio }\end{array}$ & $\begin{array}{c}e^{\text {Byob* }} \\
(95 \% \text { Cl) }\end{array}$ & $\begin{array}{c}p- \\
\text { value }\end{array}$ & $\begin{array}{c}\text { Percent } \\
\text { increase } \\
\text { F /10yr* } \\
\text { (\%) }\end{array}$ & $\begin{array}{l}\text { Mean Age } \\
\text { at } \\
\text { Migration } \\
<21 y / \\
\geq 21 y\end{array}$ & $\begin{array}{l}\text { Mean } \\
\text { Y.O.B. } \\
<21 \mathrm{yl} \\
\geq 21 \mathrm{y}\end{array}$ & $\begin{array}{c}\text { Sex Ratio } \\
\text { Comparison }^{\dagger} \\
<21 / \geq 21 \\
p \text {-value }\end{array}$ \\
\hline $\begin{array}{c}\text { ALL } \\
\text { Regions }\end{array}$ & 2531 & 2.17 & $\begin{array}{c}1.16 \\
(109-1.23) \\
\end{array}$ & $<0.001$ & 3.13 & $\begin{array}{l}8.6 / \\
29.3\end{array}$ & $\begin{array}{c}1951.7 / \\
1944.3 \\
\end{array}$ & $\begin{array}{c}2.87 / 1.96 \\
p=0.004\end{array}$ \\
\hline $\begin{array}{l}\text { Northern } \\
\text { Europe }^{\ddagger}\end{array}$ & 1279 & 2.14 & $\begin{array}{c}1.17 \\
(1.06-1.28)\end{array}$ & 0.001 & 3.3 & $\begin{array}{l}7.9 / \\
28.6\end{array}$ & $\begin{array}{c}1950.0 / \\
1941.5\end{array}$ & $\begin{array}{c}2.89 / 1.94 \\
p=0.018\end{array}$ \\
\hline $\begin{array}{l}\text { Southern } \\
\text { Europe }^{\S}\end{array}$ & 480 & 1.89 & $\begin{array}{c}1.27 \\
(1.10-1.45) \\
\end{array}$ & $<0.001$ & 5.5 & $\begin{array}{l}8.7 / \\
28.6\end{array}$ & $\begin{array}{c}1951.7 / \\
1945.2\end{array}$ & $\begin{array}{c}2.33 / 1.63 \\
p=0.060\end{array}$ \\
\hline USA & 355 & 2.86 & $\begin{array}{c}1.07 \\
(0.89-1.28) \\
\end{array}$ & 0.466 & 1.3 & $\begin{array}{l}9.0 / \\
30.1\end{array}$ & $\begin{array}{c}1950.4 / \\
1948.1\end{array}$ & $\begin{array}{l}3.61 / 2.64 \\
p=0.395\end{array}$ \\
\hline Other & 417 & 2.53 & $\begin{array}{c}1.04 \\
(0.87-1.23)\end{array}$ & 0.660 & 0.8 & $\begin{array}{l}10.3 / \\
30.3\end{array}$ & $\begin{array}{l}1960.2 / \\
1952.9\end{array}$ & $\begin{array}{c}2.67 / 2.32 \\
p=0.367\end{array}$ \\
\hline $\begin{array}{l}{ }^{*} \mathrm{e}^{\mathrm{By}} \\
\text { are c } \\
\text { †Fis } \\
{ }^{ \pm} \text {Inc } \\
\text { Swe } \\
\text { Gree }\end{array}$ & $\begin{array}{l}\text { (factor } \\
\text { rived fr } \\
\text { ers exac } \\
\text { ded in } ~ \\
\text { en, Russ } \\
\text { e. Hung }\end{array}$ & $\begin{array}{l}\text { which se } \\
\text { regressi } \\
\text { st, signif } \\
\text { urope: B } \\
\text { UK, Ukı } \\
\text {, Italy, P }\end{array}$ & $\begin{array}{l}\text { ratio increas } \\
\text { modelling } \\
\text { ance thresho } \\
\text { lgium, Denm } \\
\text { ine. }{ }^{\S} \text { Include } \\
\text { rtugal, Roma }\end{array}$ & $\begin{array}{l}\text { s per } 10 \mathrm{y} \\
\text { y.o.b as } \\
\text { l } p<0.05 \\
\text { rk, Germ } \\
\text { in S.Eur } \\
\text { ia, Spain }\end{array}$ & $\begin{array}{l}\text { riod) and } \\
\text { redictor o } \\
\text { Ireland, } \\
\text { : Austria, } \\
\text { vitzerland }\end{array}$ & $\begin{array}{l}\text { roximate } \mathrm{p} \\
\mathrm{x} \text { ratio } \\
\text { therlands, I } \\
\text { lgaria, Cze } \\
\text { rmer Yugo }\end{array}$ & $\begin{array}{l}\text { htage in } \\
\text { ay, Lat } \\
\text { epublic } \\
\text { a }\end{array}$ & $\begin{array}{l}\text { ase per } 10 y \\
\text { Poland, } \\
\text { ance, }\end{array}$ \\
\hline
\end{tabular}




\section{DISCUSSION}

Examining the sex ratio of different immigrant groups upon immigration to Canada considers how environmental effect(s) may impact MS risk and can shed light on the timing of these effects and changing risk patterns in different regions of the world. Canada has welcomed over 13 million immigrants since 1901 and in 2006 19.6\% of the population was foreign-born ${ }^{26}$. Combined with the nation-wide ascertainment of a large proportion of Canadian MS cases by the CCPGSMS, this provided an ideal opportunity to study the changes in sex ratio of MS patients immigrating to an area of high MS risk. MS prevalence in Canada is $\sim 240$ per 100000 , one of the highest rates worldwide ${ }^{28}$.

Increasing rates of MS incidence, often ascribed to ascertainment bias, improved detection methods, or study design, have been clearly shown to represent a real increase in Canada and elsewhere 293031 . Sex ratio serves as an internal variable to measure incidence changes over time within the same study group. Although changes in diagnostic methods cannot be completely ruled out, it is unlikely to account for more than a small effect of the observed changes. Presumably any ascertainment changes over time would be equally applicable to both sexes, at least over the longer term, and in Canada time to diagnosis does not differ by sex.

Year of birth was found to be a significant predictor of sex ratio in the immigrants and the rate of change was slightly larger than for the Canadian-born individuals (increasing by a factor of 1.16 versus 1.11 per $10 \mathrm{y}$ period). The rising F:M ratios may be suggestive of an increasing risk for females in the country of origin, an underlying 
worldwide background increase, or that the female risk is increased upon immigration to Canada. It may also be a combination of these.

Mean sex ratios and rates of change varied by region of origin. The overall mean sex ratios were highest for immigrants from the USA, Northern Europe ( $>60 \%$ from UK), and Australasia, regions which generally have relatively high sex ratios ${ }^{632}$. The rate of increase was steepest for migrants from Southern European countries, although the overall mean F:M ratio remained relatively low for this group. Mean sex ratios were also low for Africa (excluding South Africa) and the Middle East, although higher than previously reported ratios for these regions ${ }^{33-35}$, suggestive that some female risk protection is acquired from the country of birth. Overall these findings suggest a modification of risk upon immigration to Canada which does not complete override protective effects which may result from genetic background and/or epigenetic effects ${ }^{3637}$, and/or possible environmental factors acting around the time of birth in the country of origin.

There is evident year to year variation in the increasing sex ratio, which may be resulting from natural variability and chance, or year-to-year temporal changes in environmental factors. Comparing peak and nadir y.o.b.'s to other datasets from nonCanadian patients would be insightful in deciphering these trends. Changes in lifestyle factors of women could account for the overall increase by birth year, as well as the variability in rates by birthplace. These include sunlight exposure, timing of childbearing, increase in women in the workplace, dietary changes, and smoking, among others. These are alterations that could apply to a given country/region over time or in the case of immigration, to a given individual whose demographic profile 
changes after emigrating. Upon settling in Canada, many immigrant groups will experience shifts in demographic characteristics, some of which have been considered susceptibility factors in MS ${ }^{38} 39$. For some immigrants these include increased socioeconomic status, decreased annual sunshine, living in city/urban area, and higher education level 3839

The timing of exposure to infection in childhood is also to be considered. Although not applicable to all immigrant groups, as socioeconomic status improves and lifestyles change (become more 'westernized'), an associated decrease in exposure to certain infections in early life could increase the risk of autoimmune disorders. This has been previously suggested for individuals in southern USA and Europe, which have been traditionally more exposed to infections in childhood, but recent improvements in lifestyle may have decreased the early life exposure ${ }^{32} 39$.

A higher tendency for females or males to settle in Canada, would serve to inflate or decrease the ratio. Furthermore, if the proportion of females immigrating over time was increasing, this would have the effect of an apparent increasing sex ratio, or vice versa. To control for this variable we investigated Canadian census data on immigration from 1905 to present ${ }^{26}$. We found that the sex ratio in immigrants was close to unity for most of the time period studied.

The influence of age at immigration to Canada was considered. With the recognition that environmental factors in MS act at a broad population level, we considered the impact of being raised in the Canadian environment versus being introduced to it later in life, presumably after most MS risk is acquired. We observed that earlier ages of 
immigration, of those destined to get MS, were significantly associated with higher risk of being female versus male. In addition, the sex ratio in immigrants migrating in adulthood $(\geq 21)$ was significantly lower than in individuals immigrating early in life $(<21)$. It has been previously reported that earlier age of migration increases individuals' risk of MS when migrating to countries with relatively higher MS prevalence $^{222340}$. Here we found the case to be similar for female risk in Canada.

For analyses, adulthood was defined as 21 years, however this does not imply some critical cut-off age before which all MS risk is acquired. This dividing age was selected by a methodological approach to determine the immigration age at which differences in sex ratio were most significant. The overall findings indicated that the impact on changing female incidence could be extended later than this, and without a larger sample size it remains challenging to resolve the possibility of critical ages of MS risk exposure. Another challenge in interpretation of age at immigration effects on risk is that they are intertwined with the concomitant effect of birth year on sex ratio; individuals that migrated later in life inherently have an earlier mean y.o.b. than those with early age at migration. Secondly, it is most likely that the effects responsible for increasing sex ratio are the same as those influencing higher female risk with early migration age, limiting the ability to decipher the extent to which they are acting independently.

It is likely that MS incidence is changing in various countries of origin studied here, if not worldwide. This makes it difficult to interpret the extent to which the risk effects altering the sex ratio are specific to Canada. To decipher the reasons for geographical differences further studies on sex ratio and incidence changes in more regions are 
warranted. This proves difficult in many countries however, as nation-wide access, consistent methods for serial sampling over time and/or large datasets are not often available.

The mechanism for the growing female preponderance is still not clear, but it appears be environmental in nature, perhaps due to gene-environment interactions. It is notable that epigenetic effects are also often gender-specific. The results of the current study show that the sex ratio in immigrants to Canada is increasing. This was true generally of migrants from all regions of origin. The rate of increase was highest in immigrants of Southern-European origin. The findings suggest that moving to Canada - an area of relatively high socio-economic status, low seasonal UV exposure, immigrant distribution mainly in city or urban settings - has effects on MS incidence in females. Expanding the current study to look specifically at incidence and sex ratio over time in the regions considered here is a logical future direction. Examining change, or lack of change, in incidence rates in different regions worldwide could provide clues as to the nature of environmentally based risk factors. Moreover, elucidating such environmental influences is a clear step in defining preventable actions to decrease MS risk. 
Competing interests: None declared

\section{Role of the funding source}

The sponsor of the present study had no role in the study design, data collection, data analysis, data interpretation, nor writing of the manuscript.

The corresponding author has the right to grant on behalf of all authors and does grant on behalf of all authors, an exclusive licence (or non exclusive for government employees) on a worldwide basis to the BMJ Publishing Group Ltd and its Licensees to permit this article (if accepted) to be published in the Journal of Neurology, Neurosurgery \& Psychiatry editions and any other BMJPGL products to exploit all subsidiary rights, as set out in our licence

Members of the Canadian Collaborative Study Group include: J.J-F. Oger, D.W.

Paty, S.A. Hashimoto, V. Devonshire, J. Hooge, J, P.Smythe, T. Traboulsee

(Vancouver), L. Metz (Calgary), S. Warren (Edmonton), W. Hader (Saskatoon), R.

Nelson, M. Freedman (Ottawa), D. Brunet (Kingston), J. Paulseth (Hamilton), G.

Rice, M. Kremenchutzky (London), P. O’Connor, T. Gray, M. Hohol (Toronto), P.

Duquette, Y. Lapierre (Montreal), J-P. Bouchard (Quebec City), T. J. Murray, V.

Bhan, C. Maxner (Halifax), W. Pryse-Phillips, M. Stefanelli (St. Johns). 


\section{Acknowledgments}

We would like to thank the members of the Sadovnick lab, in particular Kevin Fisher and Maria Crisoula for their help with amassing and organizing the data. We also thank the members of the Ebers lab, including Katie Morrison and Michael Chao. This study was made possible through grants from the MS Society of Canada and its research foundation. S-MO was supported by a Clarendon scholarship (University of Oxford) and BMH was supported by a UK MS Society studentship. SVR was funded by a UK MRC studentship. All participants provided informed consent and the investigation complies with current guidelines and ethics.

\section{Contributions}

S-MO participated in the writing of the manuscript, literature searches, data analysis, and production of figures and tables. BMH participated in the writing of the report and did literature searches. IMY compiled the raw data and managed the database. DB was involved in the statistical analyses. SVR and DAD contributed to editing, reference searching, and intial set-up. GE and ADS planned and executed the study with their students and colleagues. 


\section{References}

1. Larsen JP, Kvaale G, Riise T, Nyland H, Aarli JA. An increase in the incidence of multiple sclerosis in western Norway. Acta Neurol Scand 1984;70(2):96-103.

2. Phadke JG, Downie AW. Epidemiology of multiple sclerosis in the north-east (Grampian region) of Scotland--an update. J Epidemiol Community Health 1987;41(1):5-13.

3. McLeod JG, Hammond SR, Hallpike JF. Epidemiology of multiple sclerosis in Australia. With NSW and SA survey results. Med J Aust 1994;160(3):11722.

4. Koch-Henriksen N. The Danish Multiple Sclerosis Registry: a 50-year followup. Mult Scler 1999;5(4):293-6.

5. Pugliatti M, Sotgiu S, Solinas G, Castiglia P, Pirastru MI, Murgia B, et al. Multiple sclerosis epidemiology in Sardinia: evidence for a true increasing risk. Acta Neurol Scand 2001;103(1):20-6.

6. Noonan CW, Kathman SJ, White MC. Prevalence estimates for MS in the United States and evidence of an increasing trend for women. Neurology 2002;58(1):136-8.

7. Barnett MH, Williams DB, Day S, Macaskill P, McLeod JG. Progressive increase in incidence and prevalence of multiple sclerosis in Newcastle, Australia: a 35-year study. J Neurol Sci 2003;213(1-2):1-6.

8. Wallin MT, Page WF, Kurtzke JF. Multiple sclerosis in US veterans of the Vietnam era and later military service: race, sex, and geography. Ann Neurol 2004;55(1):65-71.

9. Nicoletti A, Patti F, Lo Fermo S, Sorbello V, Reggio E, Maimone D, et al. Possible increasing risk of multiple sclerosis in Catania, Sicily. Neurology 2005;65(8):1259-63.

10. Grytten N, Glad SB, Aarseth JH, Nyland H, Midgard R, Myhr KM. A 50year follow-up of the incidence of multiple sclerosis in Hordaland County, Norway. Neurology 2006;66(2):182-6.

11. Debouverie M, Pittion-Vouyovitch S, Louis S, Roederer T, Guillemin F. Increasing incidence of multiple sclerosis among women in Lorraine, Eastern France. Mult Scler 2007;13(8):962-7.

12. Granieri E, Economou NT, De Gennaro R, Tola MR, Caniatti L, Govoni V, et al. Multiple sclerosis in the province of Ferrara : evidence for an increasing trend. $J$ Neurol 2007;254(12):1642-8. 
13. Hirst C, Ingram G, Pickersgill T, Swingler R, Compston DA, Robertson NP. Increasing prevalence and incidence of multiple sclerosis in South East Wales. J Neurol Neurosurg Psychiatry 2009;80(4):386-91.

14. Orton SM, Herrera BM, Yee IM, Valdar W, Ramagopalan SV, Sadovnick AD, et al. Sex ratio of multiple sclerosis in Canada: a longitudinal study. Lancet Neurol 2006;5(11):932-6.

15. Grimaldi LM, Salemi G, Grimaldi G, Rizzo A, Marziolo R, Lo Presti C, et al. High incidence and increasing prevalence of MS in Enna (Sicily), southern Italy. Neurology 2001;57(10):1891-3.

16. Ford HL, Gerry E, Airey CM, Vail A, Johnson MH, Williams DR. The prevalence of multiple sclerosis in the Leeds Health Authority. J Neurol Neurosurg Psychiatry 1998;64(5):605-10.

17. McDonnell GV, Hawkins SA. An epidemiologic study of multiple sclerosis in Northern Ireland. Neurology 1998;50(2):423-8.

18. Robertson N, Deans J, Fraser M, Compston DA. Multiple sclerosis in the north Cambridgeshire districts of East Anglia. J Neurol Neurosurg Psychiatry 1995;59(1):71-6.

19. Rothwell PM, Charlton D. High incidence and prevalence of multiple sclerosis in south east Scotland: evidence of a genetic predisposition. $J$ Neurol Neurosurg Psychiatry 1998;64(6):730-5.

20. Alonso A, Hernan MA. Temporal trends in the incidence of multiple sclerosis: a systematic review. Neurology 2008;71(2):129-35.

21. Kurtzke JF, Beebe GW, Norman JE, Jr. Epidemiology of multiple sclerosis in US veterans: III. Migration and the risk of MS. Neurology 1985;35(5):672-8.

22. Dean G, Kurtzke JF. On the risk of multiple sclerosis according to age at immigration to South Africa. Br Med J 1971;3(5777):725-9.

23. Dean G, Elian M. Age at immigration to England of Asian and Caribbean immigrants and the risk of developing multiple sclerosis. J Neurol Neurosurg Psychiatry 1997;63(5):565-8.

24. Pugliatti M, Riise T, Sotgiu MA, Satta WM, Sotgiu S, Pirastru MI, et al. Evidence of early childhood as the susceptibility period in multiple sclerosis: space-time cluster analysis in a Sardinian population. Am $J$ Epidemiol 2006;164(4):326-33.

25. Sadovnick AD, Risch NJ, Ebers GC. Canadian collaborative project on genetic susceptibility to MS, phase 2: rationale and method. Canadian Collaborative Study Group. Can J Neurol Sci 1998;25(3):216-21.

26. Statistics Canada S. StatsCan Census Data, 2001. 
27. A language and environment for statistical computing [program]. Vienna: Foundation for Statistical Computing, 2004.

28. Beck CA, Metz LM, Svenson LW, Patten SB. Regional variation of multiple sclerosis prevalence in Canada. Mult Scler 2005;11(5):516-9.

29. Ranzato F, Perini P, Tzintzeva E, Tiberio M, Calabrese M, Ermani M, et al. Increasing frequency of multiple sclerosis in Padova, Italy: a 30 year epidemiological survey. Mult Scler 2003;9(4):387-92.

30. Modrego PJ, Pina MA. Trends in prevalence and incidence of multiple sclerosis in Bajo Aragon, Spain. J Neurol Sci 2003;216(1):89-93.

31. Compston A, Lassmann H, Wekerle H, Noseworthy J, McDonald WI, Miller DH, et al. McAlpine's Multiple Sclerosis,. 4th Ed ed. Philadelphia: Churchill livingstone, Elsevier, 2005.

32. Pugliatti M, Rosati G, Carton H, Riise T, Drulovic J, Vecsei L, et al. The epidemiology of multiple sclerosis in Europe. Eur $J$ Neurol 2006;13(7):700-22.

33. Pugliatti M, Sotgiu S, Rosati G. The worldwide prevalence of multiple sclerosis. Clin Neurol Neurosurg 2002;104(3):182-91.

34. Al-Din AS. Multiple sclerosis in Kuwait: clinical and epidemiological study. $J$ Neurol Neurosurg Psychiatry 1986;49(8):928-31.

35. Al-Araji A, Mohammed AI. Multiple sclerosis in Iraq: does it have the same features encountered in Western countries? J Neurol Sci 2005;234(12):67-71.

36. Ramagopalan SV, Dyment DA, Ebers GC. Genetic epidemiology: the use of old and new tools for multiple sclerosis. Trends Neurosci 2008.

37. Chao MJ, Ramagopalan SV, Herrera BM, Lincoln MR, Dyment DA, Sadovnick AD, et al. Epigenetics in multiple sclerosis susceptibility: difference in transgenerational risk localizes to the major histocompatibility complex. Hum Mol Genet 2009;18(2):261-6.

38. Giovannoni G, Ebers G. Multiple sclerosis: the environment and causation. Curr Opin Neurol 2007;20(3):261-8.

39. Pugliatti M, Harbo HF, Holmoy T, Kampman MT, Myhr KM, Riise T, et al. Environmental risk factors in multiple sclerosis. Acta Neurol Scand Suppl 2008; 188:34-40.

40. Kurtzke JF. Multiple sclerosis in time and space--geographic clues to cause. $J$ Neurovirol 2000;6 Suppl 2:S134-40. 


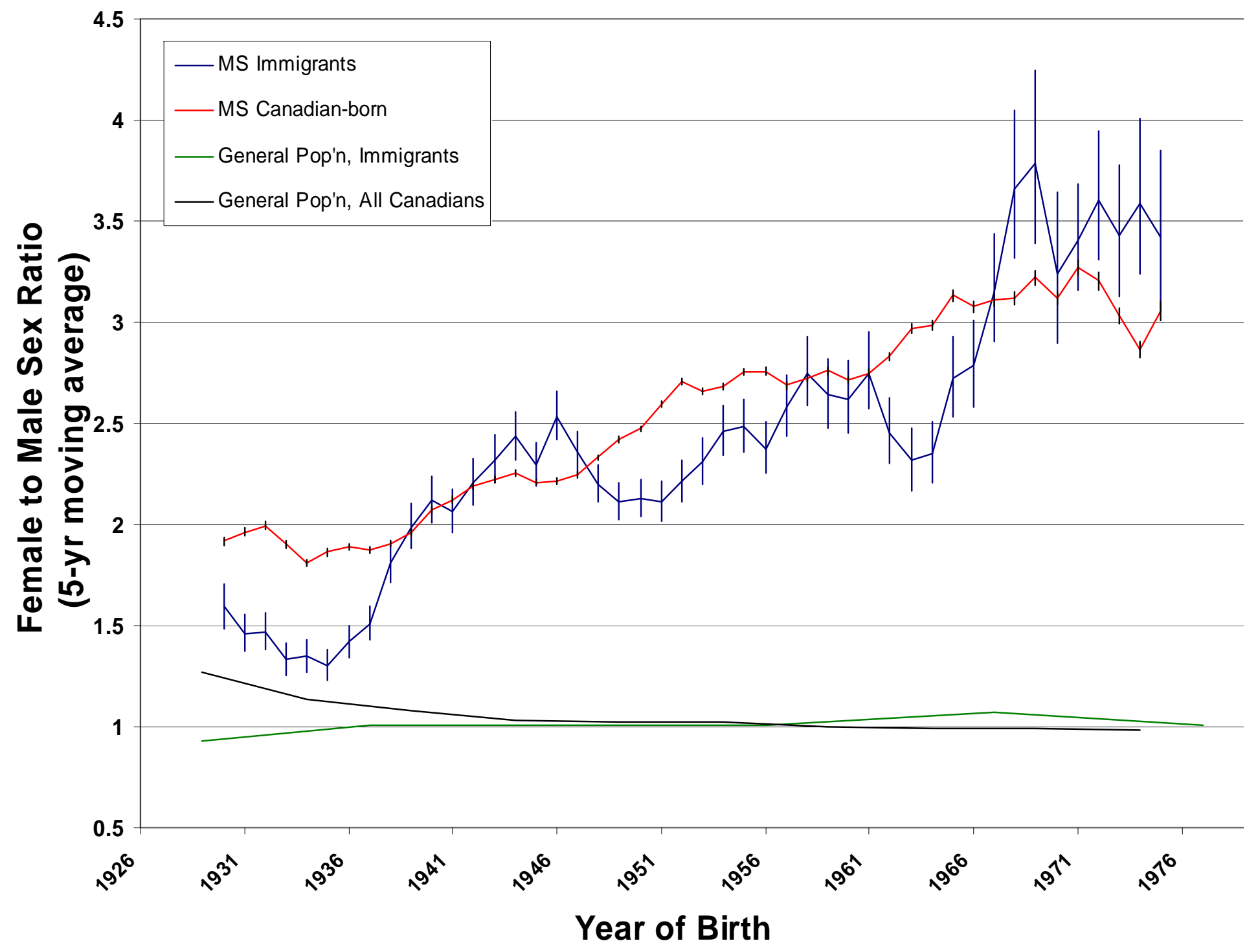

Figure 1. Sex ratio and $95 \%$ Cls of MS patients that were born outside of Canada (immigrants) by year of birth from 1930 to 1975 (blue). Logistic regression analysis showed the increasing sex ratio trend was significant $\left(p<10^{-5}\right)$ and Spearman rank correlation was $r=0.61(p<0.001)$. For comparison, the sex ratio of Canadian-born MS patients (red), the general population (black,) and the general Immigrant population in Canada (green line) are illustrated (2001 census, Statistics Canada ${ }^{28}$ ). 